\title{
IL-1 in osteoarthritis: time for a critical review of the
}

\section{literature [version 1; peer review: 2 approved]}

\author{
Tonia L. Vincent (iD \\ Centre for OA Pathogenesis Versus Arthritis, Kennedy Institute of Rheumatology, University of Oxford, Oxford, OX3 7FY, UK
}

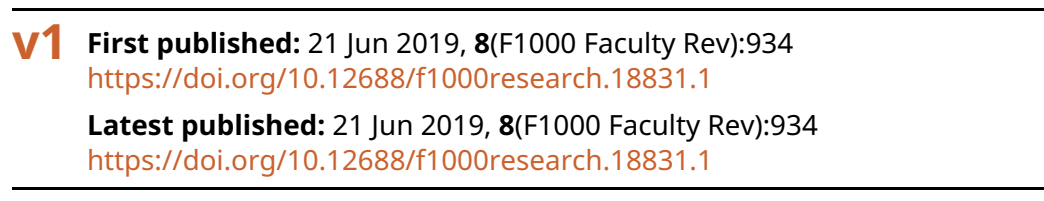

\section{Abstract}

The concept of interleukin-1 (IL-1) as a target in osteoarthritis (OA) has been an attractive one for many years. It is a highly potent inducer of cartilage degradation, causing the induction of mRNA and controlling the bioavailability of disease-relevant proteases such as ADAMTS5 and MMP13. It drives synovitis and can induce other disease-relevant genes such as nerve growth factor, a key pain sensitiser in OA. However, the quality of evidence for its involvement in disease is modest. Descriptive studies have demonstrated expression of IL-1 a and $\beta$ in OA cartilage and elevated levels in the synovial fluid of some patients. Agnostic transcriptomic and genomic analyses do not identify IL-1 as a key pathway. In vivo models show a conflicting role for this molecule; early studies using therapeutic approaches in large animal models show a benefit, but most murine studies fail to demonstrate protection where the ligands (IL-1 $\alpha / \beta)$, the cytokine activator (IL-1-converting enzyme), or the receptor (IL-1R) have been knocked out. Recently, a number of large double-blind randomised controlled clinical studies targeting IL-1 have failed. Enthusiasm for IL1 as a target in OA is rapidly dwindling.

\section{Keywords}

Interleukin-1, catabolin, osteoarthritis, cartilage

\section{Open Peer Review \\ Approval Status \\ 1 \\ 2 \\ version 1 \\ 21 Jun 2019 \\ Faculty Reviews are review articles written by the prestigious Members of Faculty Opinions. The articles are commissioned and peer reviewed before publication to ensure that the final, published version is comprehensive and accessible. The reviewers who approved the final version are listed with their names and affiliations. \\ 1. Tariq M. Haqqi, Northeast Ohio Medical University, Rootstown, Ohio, USA \\ 2. Charles J. Malemud, Case Western Reserve University School of Medicine, Cleveland," USA}

Any comments on the article can be found at the end of the article. 
Corresponding author: Tonia L. Vincent (tonia.vincent@kennedy.ox.ac.uk)

Author roles: Vincent TL: Conceptualization, Data Curation, Writing - Original Draft Preparation, Writing - Review \& Editing

Competing interests: The author declares that she has no competing interests other than the fact that she trained under Professor Jeremy Saklatvala who had previously characterised catabolin.

Grant information: This work was supported by a grant from Versus Arthritis (21621).

The funders had no role in study design, data collection and analysis, decision to publish, or preparation of the manuscript.

Copyright: ( 2019 Vincent TL. This is an open access article distributed under the terms of the Creative Commons Attribution License, which permits unrestricted use, distribution, and reproduction in any medium, provided the original work is properly cited.

How to cite this article: Vincent TL. IL-1 in osteoarthritis: time for a critical review of the literature [version 1; peer review: 2 approved] F1000Research 2019, 8(F1000 Faculty Rev):934 https://doi.org/10.12688/f1000research.18831.1

First published: 21 Jun 2019, 8(F1000 Faculty Rev):934 https://doi.org/10.12688/f1000research.18831.1 


\section{Introduction}

Evidence to support a molecular role in disease is usually amassed from a combination of biological plausibility, demonstration of disease-relevant activity in vitro, descriptive studies in disease tissue samples and genetic analyses. The quality of evidence is improved when it is possible to perform functional validation studies in relevant animal models in which the molecule is knocked down (or out) or to use drugs that target the molecule in question. Ultimately, definitive clinical studies will reveal the success of one's endeavours but with the caveat that you have selected your patient group appropriately and have sensitive and relevant outcome measures. In practice, it is hard to build a robust case to justify the large investment required to support a clinical trial and this is further complicated by publication bias and uncritical analysis. In this commentary, I review the evidence for interleukin-1 (IL-1), arguably the best-investigated cytokine in osteoarthritis (OA) pathogenesis, and take a critical look at the quality of evidence that supports its role in disease. This is not intended to be an exhaustive review of all the literature on IL-1 in OA. Rather, I have selected key articles that add substantially to our knowledge irrespective of whether they report 'positive' or 'negative' outcomes.

\section{Interleukin-1, the history}

The term 'IL-1' was first ascribed to a potent cytokine activity that was generated by activated macrophages, and shown to activate $\mathrm{T}$ cells ${ }^{1-3}$. This molecule was initially termed 'lymphocyte-activating factor' but was reclassified to IL-1 in $1979^{4}$. Over the following 15 years, a number of other cell activities were ascribed to IL-1. These included 'mononuclear cell factor' 5 and 'endogenous (or leukocytic) pyrogen', the latter being able to induce fever by direct stimulation of the hypothalamus ${ }^{6,7}$. Immune cells were not the only focus of this early work. Connective tissue cells were also shown to make and respond to an IL-1-like activity ${ }^{8,9}$, the most striking of which was termed 'catabolin' ${ }^{10}$ (Table 1).

\section{Biological plausibility}

Catabolin was initially described in co-cultures of synovium with articular cartilage ${ }^{11}$ and subsequently purified and characterised from non-adherent porcine leukocytes (principally lymphocytes $)^{10,12-14}$. It caused profound loss of proteoglycan from cartilage in vitro and in vivo which was deemed to be due to catabolic activity, as well as suppression of new proteoglycan synthesis $^{15,16}$. The catabolic activity that was demonstrated in chondrocytes was indirect as dead cartilage was non-responsive

Table 1. Cellular activities eventually attributed to IL-1.

\begin{tabular}{|l|l|}
\hline Interleukin-1 (IL-1) synonym & Role \\
\hline Leukocyte-activating factor & T-cell activation \\
\hline Mononuclear cell factor & IL-2 induction \\
\hline Catabolin & $\begin{array}{l}\text { Cartilage degradation } \\
\text { Synovitis }\end{array}$ \\
\hline $\begin{array}{l}\text { Endogenous pyrogen/ } \\
\text { Leukocyte pyrogen }\end{array}$ & Fever \\
\hline
\end{tabular}

to catabolin, and it was postulated that catabolin induced the enzymes responsible for aggrecan degradation. For a time, there was a consensus that this IL-1-like activity was not IL-1 as the isoelectric point ( $\mathrm{pI}$ ) of catabolin was acidic (4.8-5.0) compared with IL-1, which had a pI of between 6.5 and 7 . Subsequent purifications by several groups in mouse, human and pig revealed two distinct molecular species, which have similar biological activities ${ }^{17}$. When these molecules were eventually cloned, they turned out to have only modest amino acid sequence homology (20\%) and distinct pIs. They were termed IL- $1 \alpha$ and IL-1 $\beta$, reflecting the acidic and basic proteins respectively ${ }^{17,18}$. Both ligands bound to the same two-chain receptor (IL-1R) with high affinity $\left(\mathrm{k}_{\mathrm{d}}=10^{-10}\right)^{19,20}$. Another molecule with some shared homology with IL- $1 \alpha$ and IL- $1 \beta$ was discovered. This turned out to be the IL-1R antagonist (IL-1Ra), a natural inhibitor of IL-1 signalling ${ }^{21-23}$.

IL- $1 \alpha$ and IL- $1 \beta$ are made as pro-proteins which lack signal peptides and are retained in the cytoplasm ${ }^{24}$. Unlike pro-IL- $1 \alpha$, pro-IL-1 $\beta$ lacks biological activity and must be processed by caspase 1, also known as IL-1-converting enzyme (ICE) ${ }^{25,26}$. Processing by caspase 1 is linked to secretion of IL-1 $\beta$ and this therefore is a requirement for its biological effects. IL-18 is processed in a similar fashion. These effects are dependent upon activation of the 'inflammasome' complex and indicate that IL-1 biological activity requires a two-hit process: induction of the mRNA followed by processing of the pro-molecule prior to secretion from the cell ${ }^{27}$.

\section{In vitro disease-relevant activity}

IL-1 was hugely influential in the discovery of the proteases responsible for cartilage degradation in OA. IL-1 was able to induce a number of known matrix metalloproteinases (MMPs) in vitro and suppress proteoglycan synthesis, ${ }^{9,16,28-30}$ but it was not until the large-scale purification of medium from IL-1stimulated cartilage that the first aggrecanase (a disintegrin with thrombospondin motif 4, or ADAMTS4) was identified ${ }^{31}$. By homology searching, this led to the identification of ADAMTS5 ${ }^{18}$. The role of ADAMTS5, but not ADAMTS4, in OA pathogenesis was subsequently shown by Glasson et al. in mice $(2005)^{32,33}$. There are conflicting views on whether ADAMTS5 and ADAMTS4 are both pathogenic mediators in human $\mathrm{OA}^{21,23}$. Interestingly, in most species, ADAMTS5 is constitutively expressed and is not much regulated by IL-1 at the mRNA level ${ }^{34}$, even though its activity is strongly IL-1regulated $^{21}$. Regulation of activity is thought to be controlled by the re-uptake of ADAMTS5 at the cell surface by the scavenger receptor $\mathrm{LRP} 1^{35,36}$. It is worth noting that $\mathrm{IL}-1$ is used as an exemplar in these studies and is ideally suited because of its potency and understood mechanisms of action. Other cytokines, including tumour necrosis factor $(\mathrm{TNF})^{37}$, retinoic acid ${ }^{34,38}$ and oncostatin $\mathrm{M}^{39}$, also are strong inducers of cartilage catabolism in vitro.

\section{Interleukin-1 regulation in human osteoarthritis tissues}

A standard initial approach to validation of candidate molecules in disease almost always involves the demonstration that the 
molecule is upregulated in diseased tissues. This is challenging in OA in particular because of difficulties in obtaining normal tissue as a comparator. IL-1 is highly potent and usually present at very low concentrations. It is not easy to detect by conventional enzyme-linked immunosorbent assay or even by higher-sensitivity assays such as the MesoScale Discovery platform ${ }^{40}$. However, using high-sensitivity assays, some groups have detected low levels $(<1 \mathrm{pM})$ of IL- 1 in the synovial fluid of some patients with OA and rarely in normal joints ${ }^{41}$. There are studies reporting positive immunohistochemistry for IL-1 $\alpha$ and IL-1 $\beta$ and ICE as well as in situ hybridisation data for ICE in established human OA cartilage ${ }^{42,43}$. However, these studies compare expression levels within OA tissue and do not compare with normal tissue. These controls are especially important when we consider that IL-1 is made as a pro-enzyme and that intracellular staining does not correlate with secretion and activity. Moreover, work from our group previously showed that simple mechanical injury (that occurs at the time of tissue dissection) is a strong inducer of pro-IL-1 in normal healthy tissue and could easily confound the analysis ${ }^{44}$ (Table 2).

Counting the IL-1-positive cells within the synovium of patients with OA and rheumatoid arthritis (RA) demonstrates that OA synovial cells are much less likely to be positive (20\%) than RA cells $(60 \%)^{6,7,45}$. In several similar studies, OA tissue is generally regarded as the negative control, so again normal tissue is not included.

\section{Molecular studies}

Microarray studies potentially allow one to examine regulated genes in disease in an unbiased fashion. Early array studies in OA cartilage did not demonstrate elevation of $I L-1$ mRNA in OA compared with normal cartilage ${ }^{46}$ or in lesional compared with non-lesional OA tissue ${ }^{47}$. In a larger study by Aigner et al., who studied 4000 genes in 78 patient and control samples, $I L-1$ was downregulated in disease by around $50 \%{ }^{48}$. Two recent RNA sequencing (RNA-Seq) analyses deserve special mention. One study, by Soul et al., performed RNA-Seq on the articular cartilage of patients undergoing knee replacement surgery and compared gene expression with non-disease cartilage in the same joint ${ }^{49}$. An unbiased analysis identified two molecularly distinct groups within the affected OA samples. Pathway analysis revealed over-representation of complement activation pathways, innate immune responses, Wnt and transforming growth factor beta (TGF $\beta$ ) signalling. There was a notable

Table 2. Evidence for a role of IL-1 in osteoarthritis.

\begin{tabular}{|l|l|}
\hline Type of evidence & $\begin{array}{l}\text { Quality of evidence (likely role } \\
\text { in disease) }\end{array}$ \\
\hline Biological plausibility & High \\
\hline In vitro disease-relevant activity & High \\
\hline $\begin{array}{l}\text { Human osteoarthritis tissue } \\
\text { studies }\end{array}$ & $\begin{array}{l}\text { Low (not identified by agnostic } \\
\text { '-omic' analyses) }\end{array}$ \\
\hline Pre-clinical knockout studies & $\begin{array}{l}\text { Moderate (conflicting role in } \\
\text { disease) }\end{array}$ \\
\hline Human clinical studies & High (little role in disease) \\
\hline
\end{tabular}

absence of an inflammatory cytokine signature ${ }^{49}$. The first single-cell RNA-Seq study in OA articular cartilage was recently published $^{50}$. Although this study did not have normal cartilage as a comparator, $I L-1$ did not feature as a marker for one of the seven phenotypically distinct groups of OA chondrocytes. Nor was it associated with a molecular signature that predicted disease progression ${ }^{50}$.

\section{Genetics}

There are replicated candidate studies in which polymorphic variants of $I L-1$ have been shown to be increased in OA compared with a non-OA population (reviewed in 51), but $I L-1$ has not come out of any of the genome-wide association studies which have looked agnostically across the genome either by mapping polymorphic variants or by whole genome sequencing. The largest of these studies, recently published by the Zeggini group, identified 64 disease loci (52 of them novel) from over 77,000 large-joint OA cases ${ }^{52}$. Of these, four strong groups emerge: (1) $T G F \beta$ family members, including candidate genes GDF5, TGF 1 1, LTBP1, LTBP3 and SMAD3; (2) TGF $\alpha$, which has strong independent pre-clinical data to support it as a target ${ }^{53}$; (3) fibroblast growth factors (FGFs), in particular FGF 18 and its receptor FGFR3; FGF18, is showing significant promise following intra-articular injection in clinical trial ${ }^{54,55}$ and (4) ALDH1A2, encoding the enzyme that synthesises retinoic acid, a strong genome-wide association study hit in hand $\mathrm{OA}^{56}$ and now in knee. Again, the absence of an inflammatory cytokine signature is noteworthy.

\section{Pre-clinical studies}

Prior to the genetic modification era, pre-clinical OA was largely restricted to large animals (for example, dog and rabbit). A few studies looked at therapeutic targeting of IL-1 using either recombinant IL-1Ra (anakinra) or gene transfer of IL-1Ra. All of these early studies showed striking protection in rapidly progressive surgical models of OA when treatment was initiated early after surgery ${ }^{57-59}$. Similar protection was seen in rats after anterior cruciate ligament transection when treated early with recombinant intra-articular $\mathrm{IL}_{-1 \mathrm{Ra}^{60}}$. D'Lima et al. showed that caspase 1 inhibition suppressed disease in rabbits after cruciate ligament transection when delivered three times per week for 9 weeks ${ }^{61}$. The latter study could be affecting molecules other than IL-1, such as IL-18.

The first surgical models of OA in genetically modified mice were performed in 2003 by Clements et al. ${ }^{62}$. In that study, partial meniscectomy was performed in four genetically modified strains: Illb knockout, Ice knockout, Mmp3 knockout and nitric oxide synthase (Nos) knockout mice. None of these strains demonstrated reduced disease; if anything, a modest increase in disease was observed ${ }^{62}$. Kawaguchi's group also reported (although data were not included in the article) a lack of protection in Illa/Illb double-knockout mice ${ }^{63}$. Our own group has failed to see protection in Illrl knockout mice (unpublished data). Only one report of protection in the $1 l 1 b$ knockout mouse has been published and this was in a review article ${ }^{64}$, in which a $40 \%$ reduction in disease at one time point ( 8 weeks) was observed. The number of animals used in this experiment was not specified. 


\section{Human clinical studies}

One assumes that positive results in small open-label clinical studies $^{65}$ are partly responsible for driving the decision to proceed to randomised controlled trials (RCTs) in OA using IL-1 targeting therapies. These have included, most recently, two large studies by Abbvie using a dual neutralising antibody against IL- $1 \alpha$ and IL- $1 \beta$ in hand $\mathrm{OA}^{66}$ and knee $\mathrm{OA}^{67}$. Both studies failed to reach their primary outcome target and concluded lack of efficacy. Similarly, a single intra-articular injection of anakinra failed to show clinical efficacy at 3 months, the primary endpoint, in an RCT of 160 individuals with knee $\mathrm{OA}^{68}$. A randomised double-blind controlled study of an IL-1R neutralising antibody also failed to meet the primary endpoint ${ }^{69}$. Two small studies, one open-label and one placebo-controlled, demonstrated reduction in pain in individuals after knee trauma with IL-1Ra (anakinra). It is important to stress that whilst knee trauma may lead to OA over the course of 5 to 10 years in $50 \%$ of cases $^{70}$, there is no evidence that early pain after injury is indicative of OA or that inhibiting IL-1 early after injury can prevent OA developing ${ }^{71,72}$.

\section{Co-existing crystal arthropathy}

Could IL-1 still have a role in a subset of patients with OA? One reasonable hypothesis is that some patients' disease may be complicated by crystal arthritis. Calcium pyrophosphate (CPP) and basic calcium phosphate $(\mathrm{BCP})$ crystals are present in the synovial fluid of around 20 to $25 \%$ of patients with knee $\mathrm{OA}^{73}$ and CPP in $13 \%$ of patients with small-joint (hand and wrist) $\mathrm{OA}^{74}$. Although the presence of crystals in the joint does not necessarily lead to a clinical crystal arthritis, all crystals (including urate, pyrophosphate and cholesterol) are potential activators of the inflammasome pathway, resulting in caspase 1-dependent processing of intracellular pro-IL-1 ${ }^{75-77}$. In one study, urate levels within the synovial fluid correlated strongly with IL-1 $\beta$ (in those samples in which it was measurable) and IL-18 ${ }^{41}$. Radiographic disease severity correlated with levels of IL- $1^{41}$. These results identify synovial fluid urate or IL-1/IL-18 levels (or both) as potential biomarkers of disease severity. The jury is still out on whether IL-1 may be driving pathogenesis in a small subgroup of OA individuals who have an active crystal arthritis contributing to their structural and symptomatic disease ${ }^{78}$. In view of the complete lack of signal from the anti-IL-1 clinical trials, one has to assume that the proportion of such individuals within the larger OA population is small.

\section{Conclusions}

IL-1 remains the most potent inducer of cartilage degradation we know of and from the early days of 'catabolin' has been a top molecular candidate in OA. In recent years, IL-1 has proven to be a good target in diseases due to genetic defects in the inflammasome pathway, including some of the rare periodic fever syndromes, and this has been a good opportunity to validate the available therapies ${ }^{79}$. IL-1 targeting is also efficacious and licenced for use in crystal arthritis ${ }^{80}$, although it is usually reserved for those with severe disease unresponsive to first-line treatments. Randomised clinical trials in $\mathrm{OA}$ are conclusively telling us that this is not a target in OA despite all our hopes. Could this have been anticipated earlier? In retrospect, the evidence for IL-1 from the clinical data, especially those acquired from agnostic whole genome and whole transcriptome analyses, was weak. Results from pre-clinical studies were polarised in their conclusions and this calls into question the robustness of these data. Failure to reduce sources of bias e.g. through randomisation of animals, blinding experimentor to treatment group, or double blind scoring, are rarely described and probably not often performed. Studies are often under-powered and may examine outcomes at only one time point. Animal studies in particular are further confounded by a publication bias towards positive results $^{81}$. RCTs are an expensive way to disprove a major role for a molecule in disease, but the journey nonetheless brings us closer to understanding OA pathogenesis.

Grant information

This work was supported by a grant from Versus Arthritis (21621)

The funders had no role in study design, data collection and analysis, decision to publish, or preparation of the manuscript.
1. Gery I, Gershon RK, Waksman BH: Potentiation of the T-lymphocyte response to mitogens. I. The responding cell. J Exp Med. 1972; 136(1): 128-42. PubMed Abstract | Publisher Full Text | Free Full Text

2. Mizel SB: Biochemical and biological characterization of lymphocyte-activating factor (LAF) produced by the murine macrophage cell line, P388D. Ann NY Acad Sci. 1979; 332(1): 539-49. PubMed Abstract | Publisher Full Text

3. Smith KA, Lachman LB, Oppenheim JJ, et al:: The functional relationship of the interleukins. J Exp Med. 1980; 151(6): 1551-6. PubMed Abstract | Publisher Full Text | Free Full Text

4. Mizel SB, Farrar JJ: Revised nomenclature for antigen-nonspecific T-cell proliferation and helper factors. Cell Immunol. 1979; 48(2): 433-6. PubMed Abstract | Publisher Full Text

5. Mizel SB, Dayer JM, Krane SM, et al: Stimulation of rheumatoid synovial cell collagenase and prostaglandin production by partially purified lymphocyte- activating factor (interleukin 1). Proc Natl Acad Sci U S A. 1981; 78(4): 2474-7. PubMed Abstract | Publisher Full Text | Free Full Text

6. van Damme J, De Ley M, Opdenakker G, et al.: Homogeneous interferoninducing $22 \mathrm{~K}$ factor is related to endogenous pyrogen and interleukin-1. Nature. 1985; 314(6008): 266-8. PubMed Abstract | Publisher Full Text

7. Duff GW, Durum SK: Fever and immunoregulation: hyperthermia, interleukins 1 and 2, and T-cell proliferation. Yale J Biol Med. 1982; 55(5-6): 437-42. PubMed Abstract | Free Full Text

8. Dayer JM, Bréard J, Chess L, et al.: Participation of monocyte-macrophages and lymphocytes in the production of a factor that stimulates collagenase and prostaglandin release by rheumatoid synovial cells. J Clin Invest. 1979; 64(5): 1386-92.

PubMed Abstract | Publisher Full Text | Free Full Text

9. Balavoine JF, de Rochemonteix B, Williamson $\mathrm{K}$, et al.: Prostaglandin E2 and 
collagenase production by fibroblasts and synovial cells is regulated by urinederived human interleukin 1 and inhibitor(s). J Clin Invest. 1986; 78(4): 1120-4. PubMed Abstract | Publisher Full Text | Free Full Text

10. Saklatvala J, Dingle JT: Identification of catabolin, a protein from synovium which induces degradation of cartilage in organ culture. Biochem Biophys Res Commun. 1980; 96(3): 1225-31.

PubMed Abstract | Publisher Full Text

11. Fell HB, Jubb RW: The effect of synovial tissue on the breakdown of articular cartilage in organ culture. Arthritis Rheum. 1977; 20(7): 1359-71. PubMed Abstract | Publisher Full Text

12. Saklatvala J: Characterization of catabolin, the major product of pig synovial tissue that induces resorption of cartilage proteoglycan in vitro. Biochem $\mathrm{J}$. 1981; 199(3): 705-14.

PubMed Abstract | Publisher Full Text | Free Full Text

13. Saklatvala J, Sarsfield SJ: Lymphocytes induce resorption of cartilage by producing catabolin. Biochem J. 1982; 202(1): 275-8. PubMed Abstract | Publisher Full Text | Free Full Text

14. Saklatvala J, Curry VA, Sarsfield SJ: Purification to homogeneity of pig leucocyte catabolin, a protein that causes cartilage resorption in vitro. Biochem J. 1983; 215(2): 385-92.

PubMed Abstract | Publisher Full Text | Free Full Text

15. Dingle JT, Page Thomas DP, King B, et al.: In vivo studies of articular tissue damage mediated by catabolin/interleukin 1. Ann Rheum Dis. 1987; 46(7): $527-33$

PubMed Abstract | Publisher Full Text | Free Full Text

16. Tyler JA: Articular cartilage cultured with catabolin (pig interleukin 1) synthesizes a decreased number of normal proteoglycan molecules. Biochem J. 1985; 227(3): 869-78.

PubMed Abstract | Publisher Full Text | Free Full Text

17. Oppenheim JJ, Kovacs EJ, Matsushima K, et al:: There is more than one interleukin 1. Immunol Today. 1986; 7(2): 45-56. PubMed Abstract | Publisher Full Text

18. Abbaszade I, Liu RQ, Yang F, et al:: Cloning and characterization of ADAMTS11, an aggrecanase from the ADAMTS family. J Biol Chem. 1999; 274(33): 23443-50. PubMed Abstract | Publisher Full Text

19. Saklatvala J, Bird T: A common class of receptors for the two types of porcine interleukin-1 on articular chondrocytes. Lymphokine Res. 1986; 5 Suppl 1 : S99-104.

PubMed Abstract

20. Stylianou E, O'Neill LA, Rawlinson L, et al:: Interleukin 1 induces NF-kappa B through its type I but not its type II receptor in lymphocytes. J Biol Chem. 1992; 267(22): 15836-41.

PubMed Abstract

21. Ismail HM, Yamamoto K, Vincent TL, et al.: Interleukin-1 Acts via the JNK-2 Signaling Pathway to Induce Aggrecan Degradation by Human Chondrocytes. Arthritis Rheumatol. 2015; 67(7): 1826-36.

PubMed Abstract | Publisher Full Text

22. Dinarello CA: Interleukin-1 and interleukin-1 antagonism. Blood. 1991; 77(8): $1627-52$

PubMed Abstract

23. Song RH, Tortorella MD, Malfait AM, et al.: Aggrecan degradation in human articular cartilage explants is mediated by both ADAMTS-4 and ADAMTS- 5 . Arthritis Rheum. 2007; 56(2): 575-85.

PubMed Abstract | Publisher Full Text

24. Hazuda D, Webb RL, Simon $P$, et al:: Purification and characterization of huma recombinant precursor interleukin 1 beta. J Biol Chem. 1989; 264(3): 1689-93. PubMed Abstract

25. Schroder K, Tschopp J: The inflammasomes. Cell. 2010; 140(6): 821-32. PubMed Abstract | Publisher Full Text

26. F Gross O, Yazdi AS, Thomas CJ, et al:: Inflammasome activators induce interleukin-1a secretion via distinct pathways with differential requirement fo the protease function of caspase-1. Immunity. 2012; 36(3): 388-400. PubMed Abstract | Publisher Full Text | F1000 Recommendation

27. Gross O, Thomas CJ, Guarda G, et al.: The inflammasome: an integrated view. Immunol Rev. 2011: 243(1): 136-51.

PubMed Abstract | Publisher Full Text

28. Gadher SJ, Eyre DR, Duance VC, et al: Susceptibility of cartilage collagens type II, IX, X, and XI to human synovial collagenase and neutrophil elastase. Eur J Biochem. 1988; 175(1): 1-7.

PubMed Abstract | Publisher Full Text

29. van den Berg WB, van de Loo FA, Zwarts WA, et al.: Effects of murine recombinant interleukin 1 on intact homologous articular cartilage: quantitative and autoradiographic study. Ann Rheum Dis. 1988; 47(10): 855-63. PubMed Abstract | Publisher Full Text | Free Full Text

30. Lefebvre V, Peeters-Joris C, Vaes G: Modulation by interleukin 1 and tumor necrosis factor alpha of production of collagenase, tissue inhibitor of metalloproteinases and collagen types in differentiated and dedifferentiated articular chondrocytes. Biochim Biophys Acta. 1990; 1052(3): 366-78. PubMed Abstract | Publisher Full Text

31. F Tortorella MD, Burn TC, Pratta MA, et al:: Purification and cloning of aggrecanase-1: a member of the ADAMTS family of proteins. Science. 1999 284(5420): 1664-6.

PubMed Abstract | Publisher Full Text | F1000 Recommendation
32. F Glasson SS, Askew R, Sheppard B, et al.: Deletion of active ADAMTS5 prevents cartilage degradation in a murine model of osteoarthritis. Nature. 2005; 434(7033): 644-8.

PubMed Abstract | Publisher Full Text | F1000 Recommendation

33. Glasson SS, Askew R, Sheppard B, et al:: Characterization of and osteoarthritis susceptibility in ADAMTS-4-knockout mice. Arthritis Rheum. 2004; 50(8): 2547-58. PubMed Abstract | Publisher Full Text

34. Fosang AJ, Rogerson FM, East CJ, et al.: ADAMTS-5: the story so far. Eur Cell Mater. 2008; 15: 11-26.

PubMed Abstract | Publisher Full Text

35. F Yamamoto K, Troeberg L, Scilabra SD, et al:: LRP-1-mediated endocytosis regulates extracellular activity of ADAMTS-5 in articular cartilage. FASEB 2013; 27(2): 511-21.

PubMed Abstract | Publisher Full Text | Free Full Text | F1000 Recommendation

36. F Yamamoto K, Santamaria S, Botkjaer KA, et al.: Inhibition of Shedding of Low-Density Lipoprotein Receptor-Related Protein 1 Reverses Cartilage Matrix Degradation in Osteoarthritis. Arthritis Rheumatol. 2017; 69(6): 1246-56. PubMed Abstract | Publisher Full Text | Free Full Text | F1000 Recommendation

37. Saklatvala J: Tumour necrosis factor alpha stimulates resorption and inhibits synthesis of proteoglycan in cartilage. Nature. 1986; 322(6079): 547-9. PubMed Abstract | Publisher Full Text

38. Campbell MA, Handley CJ, D'Souza SE: Turnover of proteoglycans in articularcartilage cultures. Characterization of proteoglycans released into the medium. Biochem J. 1989; 259(1): 21-5. PubMed Abstract | Publisher Full Text | Free Full Text

39. Morgan TG, Rowan AD, Dickinson SC, et al:: Human nasal cartilage responds to oncostatin $\mathrm{M}$ in combination with interleukin 1 or tumour necrosis factor alpha by the release of collagen fragments via collagenases. Ann Rheum Dis. 2006; 65(2): 184-90. PubMed Abstract | Publisher Full Text | Free Full Text

40. Watt FE, Paterson E, Freidin A, et al.: Acute Molecular Changes in Synovial Fluid Following Human Knee Injury: Association With Early Clinical Outcomes. Arthritis Rheumatol. 2016; 68(9): 2129-40.

PubMed Abstract | Publisher Full Text | Free Full Text

41. Denoble AE, Huffman KM, Stabler TV, et al:: Uric acid is a danger signal of increasing risk for osteoarthritis through inflammasome activation. Proc Nat Acad Sci U S A. 2011; 108(5): 2088-93. PubMed Abstract | Publisher Full Text | Free Full Text

42. Moldovan F, Pelletier JP, Jolicoeur FC, et al.: Diacerhein and rhein reduce the ICE-induced IL-1beta and IL-18 activation in human osteoarthritic cartilage. Osteoarthritis and Cartilage. 2000; 8(3): 186-96. PubMed Abstract | Publisher Full Text

43. Saha N, Moldovan F, Tardif G, et al.: Interleukin-1beta-converting enzyme/ caspase-1 in human osteoarthritic tissues: Localization and role in th maturation of interleukin-1beta and interleukin-18. Arthritis Rheum. 1999; 42(8): $1577-87$

PubMed Abstract | Publisher Full Text

44. Gruber J, Vincent TL, Hermansson M, et al:: Induction of interleukin-1 in articular cartilage by explantation and cutting. Arthritis Rheum. 2004; 50(8): 2539-46. PubMed Abstract | Publisher Full Text

45. Farahat MN, Yanni G, Poston R, et al.: Cytokine expression in synovial membranes of patients with rheumatoid arthritis and osteoarthritis. Ann Rheum Dis. 1993; 52(12): 870-5

PubMed Abstract | Publisher Full Text | Free Full Text

46. Aigner T, Zien A, Gehrsitz A, et al:: Anabolic and catabolic gene expression pattern analysis in normal versus osteoarthritic cartilage using complementary DNA-array technology. Arthritis Rheum. 2001; 44(12): 2777-89. PubMed Abstract | Publisher Full Text

47. Sato $\mathrm{T}$, Konomi K, Yamasaki S, et al.: Comparative analysis of gene expression profiles in intact and damaged regions of human osteoarthritic cartilage. Arthritis Rheum. 2006; 54(3): 808-17. PubMed Abstract | Publisher Full Tex

48. Aigner $\mathrm{T}$, Fundel $\mathrm{K}$, Saas J, et al.: Large-scale gene expression profiling reveals major pathogenetic pathways of cartilage degeneration in osteoarthritis. Arthritis Rheum. 2006; 54(11): 3533-44. PubMed Abstract | Publisher Full Tex

49. F Soul J, Dunn SL, Anand S, et al.: Stratification of knee osteoarthritis: Two major patient subgroups identified by genome-wide expression analysis of articular cartilage. Ann Rheum Dis. 2018; 77(3): 423. PubMed Abstract | Publisher Full Text | Free Full Text | F1000 Recommendation

50. F Ji Q, Zheng $Y$, Zhang G, et al.: Single-cell RNA-seq analysis reveals the progression of human osteoarthritis. Ann Rheum Dis. 2018; 78(1): 100-10. PubMed Abstract | Publisher Full Text | Free Full Text | F1000 Recommendation

51. Ryder JJ, Garrison K, Song F, et al.: Genetic associations in peripheral joint osteoarthritis and spinal degenerative disease: A systematic review. Ann Rheum Dis. 2008; 67(5): 584-91.

PubMed Abstract | Publisher Full Text

52. F Tachmazidou I, Hatzikotoulas K, Southam L, et al.: Identification of new therapeutic targets for osteoarthritis through genome-wide analyses of UK Biobank data. Nat Genet. 2019; 51(2): 230-236.

PubMed Abstract | Publisher Full Text | Free Full Text | F1000 Recommendation

53. Appleton CTG, Usmani SE, Pest MA, et al.: Reduction in disease progression 
by inhibition of transforming growth factor $\alpha$-CCL2 signaling in experimental posttraumatic osteoarthritis. Arthritis Rheumatol. 2015; 67(10): 2691-701. PubMed Abstract | Publisher Full Text

54. Dahlberg LE, Aydemir A, Muurahainen N, et al.: A first-in-human, double-blind, randomised, placebo-controlled, dose ascending study of intra-articular rhFGF18 (sprifermin) in patients with advanced knee osteoarthritis. Clin Exp Rheumatol. 2016; 34(3): 445-50. PubMed Abstract

55. Eckstein F, Wirth W, Guermazi A, et al.: Brief Report: Intraarticular Sprifermin Not Only Increases Cartilage Thickness, but Also Reduces Cartilage Loss: Location-Independent Post Hoc Analysis Using Magnetic Resonance Imaging Arthritis Rheumatol. 2015; 67(11): 2916-22.

PubMed Abstract | Publisher Full Text | Free Full Text

56. Styrkarsdottir U, Thorleifsson G, Helgadottir HT, et al:: Severe osteoarthritis of the hand associates with common variants within the ALDH1A2 gene and with rare variants at 1p31. Nat Genet. 2014; 46(5): 498-502.

PubMed Abstract | Publisher Full Text

57. Elsaid KA, Zhang L, Shaman Z, et al:: The impact of early intra-articula administration of interleukin-1 receptor antagonist on lubricin metabolism and cartilage degeneration in an anterior cruciate ligament transection model. Osteoarthritis Cartilage. 2015; 23(1): 114-21.

PubMed Abstract | Publisher Full Text | Free Full Text

58. Caron JP, Fernandes JC, Martel-Pelletier J, et al.: Chondroprotective effect of intraarticular injections of interleukin-1 receptor antagonist in experimental osteoarthritis. Suppression of collagenase-1 expression. Arthritis Rheum. 1996; 39(9): 1535-44.

PubMed Abstract | Publisher Full Text

59. Pelletier JP, Caron JP, Evans C, et al.: In vivo suppression of early experimenta osteoarthritis by interleukin-1 receptor antagonist using gene therapy. Arthriti Rheum. 1997; 40(6): 1012-9.

PubMed Abstract | Publisher Full Text

60. Elsaid KA, Ubhe A, Shaman Z, et al:: Intra-articular interleukin-1 receptor antagonist (IL1-ra) microspheres for posttraumatic osteoarthritis: In vitro biological activity and in vivo disease modifying effect. $J$ Exp Orthop. 2016; 3(1): 18

PubMed Abstract | Publisher Full Text | Free Full Text

61. D'Lima D, Hermida J, Hashimoto S, et al:: Caspase inhibitors reduce severity of cartilage lesions in experimental osteoarthritis. Arthritis Rheum. 2006; 54(6): 1814-21.

PubMed Abstract | Publisher Full Text

62. Clements KM, Price JS, Chambers MG, et al.: Gene deletion of either interleukin1 beta, interleukin-1 beta-converting enzyme, inducible nitric oxide synthase, or stromelysin 1 accelerates the development of knee osteoarthritis in mice after surgical transection of the medial collateral ligament and partial medial meniscectomy. Arthritis Rheum. 2003; 48(12): 3452-63. PubMed Abstract | Publisher Full Text

63. Fukai A, Kamekura S, Chikazu D, et al:: Lack of a chondroprotective effect of cyclooxygenase 2 inhibition in a surgically induced model of osteoarthritis in mice. Arthritis Rheum. 2012; 64(1): 198-203.

PubMed Abstract | Publisher Full Text

64. Glasson SS: In Vivo Osteoarthritis Target Validation Utilizing GeneticallyModified Mice. Curr Drug Targets. 2007; 8(2): 367-76. PubMed Abstract | Publisher Full Text

65. Bacconnier L, Jorgensen C, Fabre S: Erosive osteoarthritis of the hand: Clinical experience with anakinra. Ann Rheum Dis. 2009; 68(6): 1078-9. PubMed Abstract | Publisher Full Text

66. F Kloppenburg M, Peterfy C, Haugen IK, et al.: Phase lla, placebo-controlled, randomised study of lutikizumab, an anti-interleukin- $1 \alpha$ and anti-interleukin$1 \beta$ dual variable domain immunoglobulin, in patients with erosive hand osteoarthritis. Ann Rheum Dis. 2019; 78(3): 413-420.

PubMed Abstract | Publisher Full Text | Free Full Text | F1000 Recommendation

67. Fleischmann RM, Bliddal H, Blanco FJ, et al:: A Phase II Trial of Lutikizumab, an Anti-Interleukin $1 \alpha / \beta$ Dual Variable Domain Immunoglobulin, in Knee Osteoarthritis Patients With Synovitis. Arthritis Rheumatol. 2019 PubMed Abstract | Publisher Full Text

68. Chevalier X, Goupille $P$, Beaulieu AD, et al:: Intraarticular injection of anakinra in osteoarthritis of the knee: A multicenter, randomized, double-blind, placebocontrolled study. Arthritis Rheum. 2009; 61(3): 344-52.

PubMed Abstract | Publisher Full Text

69. Cohen SB, Proudman S, Kivitz AJ, et al.: A randomized, double-blind study of AMG 108 (a fully human monoclonal antibody to IL-1R1) in patients with osteoarthritis of the knee. Arthritis Res Ther. 2011; 13(4): R125.

PubMed Abstract | Publisher Full Text | Free Full Text

70. Lohmander LS, Englund PM, Dahl LL, et al:: The long-term consequence of anterior cruciate ligament and meniscus injuries: Osteoarthritis. Am J Sports Med. 2007; 35(10): 1756-69.

PubMed Abstract | Publisher Full Text

71. Kraus VB, Birmingham J, Stabler TV, et al.: Effects of intraarticular IL1-Ra for acute anterior cruciate ligament knee injury: a randomized controlled pilot trial (NCT00332254). Osteoarthritis Cartilage. 2012; 20(4): 271-8. PubMed Abstract | Publisher Full Text

72. Brown C, Toth A, Magnussen R: Clinical Benefits of Intra-articular Anakinra for Persistent Knee Effusion. J Knee Surg. 2011; 24(1): 61-6. PubMed Abstract | Publisher Full Text

73. Frallonardo $\mathrm{P}$, Ramonda R, Peruzzo L, et al:: Basic calcium phosphate and pyrophosphate crystals in early and late osteoarthritis: Relationship with clinical indices and inflammation. Clin Rheumatol. 2018; 37(10): 2847-2853. PubMed Abstract | Publisher Full Text

74. Galozzi $\mathrm{P}$, Oliviero $\mathrm{F}$, Frallonardo $\mathrm{P}$, et al:: The prevalence of monosodium urate and calcium pyrophosphate crystals in synovial fluid from wrist and finger joints. Rheumatol Int. 2016; 36(3): 443-6.

PubMed Abstract | Publisher Full Text

75. F Martinon F, Pétrilli V, Mayor A, et al.: Gout-associated uric acid crystals activate the NALP3 inflammasome. Nature. 2006; 440(7081): 237-41. PubMed Abstract | Publisher Full Text | F1000 Recommendation

76. Jin C, Frayssinet $P$, Pelker R, et al:: NLRP3 inflammasome plays a critical role in the pathogenesis of hydroxyapatite-associated arthropathy. Proc Natl Acad Sci U S A. 2011; 108(36): 14867-72.

PubMed Abstract | Publisher Full Text | Free Full Text

77. $\mathrm{F}$ Duewell $\mathrm{P}$, Kono $\mathrm{H}$, Rayner $\mathrm{KJ}$, et al:: NLRP3 inflammasomes are required for atherogenesis and activated by cholesterol crystals. Nature. 2010; 464(7293): 1357-61.

PubMed Abstract | Publisher Full Text | Free Full Text | F1000 Recommendation

78. Olmez N, Schumacher HR Jr: Crystal deposition and osteoarthritis. Cur Rheumatol Rep. 1999; 1(2): 107-11.

PubMed Abstract | Publisher Full Text

79. Kuemmerle-Deschner JB, Hachulla E, Cartwright R, et al.: Two-year results from an open-label, multicentre, phase III study evaluating the safety and efficacy of canakinumab in patients with cryopyrin-associated periodic syndrome across different severity phenotypes. Ann Rheum Dis. 2011; 70(12): 2095-102. PubMed Abstract | Publisher Full Text

80. Dinarello CA: How interleukin-1ß induces gouty arthritis. Arthritis Rheum. 2010; 62(11): 3140-4.

PubMed Abstract | Publisher Full Text | Free Full Text

81. Vincent T, Malfait AM: Time to be positive about negative data? Osteoarthritis Cartilage. 2017; 25(3): 351-353.

PubMed Abstract | Publisher Full Text | Free Full Tex 


\section{Open Peer Review}

\section{Current Peer Review Status:}

\section{Editorial Note on the Review Process}

Faculty Reviews are review articles written by the prestigious Members of Faculty Opinions. The articles are commissioned and peer reviewed before publication to ensure that the final, published version is comprehensive and accessible. The reviewers who approved the final version are listed with their names and affiliations.

\section{The reviewers who approved this article are:}

\section{Version 1}

\section{Charles J. Malemud}

Division of Rheumatic Diseases, Case Western Reserve University School of Medicine, Cleveland,, $\mathrm{OH}$, USA

Competing Interests: No competing interests were disclosed.

\section{Tariq M. Haqqi}

Department of Anatomy and Neurobiology, Northeast Ohio Medical University, Rootstown, Ohio, USA Competing Interests: No competing interests were disclosed.

\section{Comments on this article}

\section{Version 1}

\section{Reader Comment ( ) 28 Jun 2019}

Timothy Hardingham, Prof Tim Hardingham, Wellcome Centre for Cell-Matrix Research, University of Manchester, UK

This an extremely timely review that questions a commonly held assumption that because IL1 can drive inflammation and cause the degradation of articular cartilage it must be responsible in vivo for the damage to cartilage in osteoarthritis. Examination of the background literature, as Tonia Vincent has done, reveals the flimsiest evidence that IL1 is active in most osteoarthritic joints and more recent holistic analysis, such as our RNAseq study of OA and non-OA cartilage (Soul et al Ann Rheum Dis 2018), showed no detectible expression in 60 OA knees at TKR and no evidence of cartilage responding to IL1 in synovial fluid, again in all patients. Tonia's review of IL1 in my view could be easily extended to TNF (and OSM), which have a similar profile of limited evidence in vivo in $O A$.

Are there OA joints in which IL1/TNF/OSM might play a part? As the review suggests, undoubtedly there are, as OA is a heterogeneous disease with many factors involved. The point is that these 
joints and/or these patients are the exceptions and targeting these pathways as pathogenic in all $\mathrm{OA}$ is a lost cause. As a research community we need to wise up and not perpetuate this myth and concentrate instead on the range of other genetic and environmental factors that predispose joints to irreversible damage and loss of function and develop methods to stratify OA to identify the subsets that will respond to specific modes of intervention.

Competing Interests: No competing interests

The benefits of publishing with F1000Research:

- Your article is published within days, with no editorial bias

- You can publish traditional articles, null/negative results, case reports, data notes and more

- The peer review process is transparent and collaborative

- Your article is indexed in PubMed after passing peer review

- Dedicated customer support at every stage

For pre-submission enquiries, contact research@f1000.com 